\title{
Highly dispersed Ni nanoparticles on 3D-mesoporous KIT-6 for CO methanation: Effect of promoter species on catalytic performance
}

\author{
Hong-Xia Cao a,b, Jun Zhang a , Cheng-Long Guo c, Jingguang G. Chen d,*, Xiang-Kun Ren a,\# \\ a Low Carbon Energy Institute, China University of Mining and Technology, Xuzhou 221008, Jiangsu, China \\ b Earth and Environmental Engineering Department, Columbia University, New York 10027, United States \\ c School of Electrical and Power Engineering, China University of Mining and Technology, Xuzhou 221116, Jiangsu, China \\ d Department of Chemical Engineering, Columbia University, New York 10027, United States
}

\section{A R T I C L E I N F O}

\section{Article history:}

Received 9 April 2017

Accepted 23 May 2017

Published 5 July 2017

\section{Keywords:}

Nickel-based catalyst

Methanation

Promoter

Support

3D-mesopore

\begin{abstract}
A B S T R A C T
Promoter-modified Ni-based catalysts were synthesized by an incipient-wetness impregnation method using 3D-mesoporous KIT- 6 as a support modified by ethylene glycol, and evaluated for the catalytic production of synthetic natural gas (SNG) from CO methanation. Characterization results suggested that the addition of promoter species could remarkably improve the low-temperature catalytic activity for $\mathrm{CO}$ methanation, which was due to a large dispersion of Ni nanoparticles, an enhanced interaction between metal and support as well as a confinement effect of 3D-mesopores. Among all catalysts, Ni-V/KIT-6 possessed the best catalytic performance, which was ascribed to the largest $\mathrm{H}_{2}$ uptake of $177.6 \mu \mathrm{mol} / \mathrm{g}$ and $\mathrm{Ni}$ dispersion of $26.5 \%$, an intimate interaction with the support from the formation of Si-O-V linkage and an enhanced confinement effect of 3D-mesopores to effectively prevent the growth of $\mathrm{Ni}$ nanoparticles and carbon filaments. In consequence, $\mathrm{Ni}-\mathrm{V} / \mathrm{KIT}-6$ displayed excellent catalytic performance as well as high catalytic stability, which can be regarded as a promising candidate for $\mathrm{CO}$ methanation.
\end{abstract}

(C) 2017, Dalian Institute of Chemical Physics, Chinese Academy of Sciences. Published by Elsevier B.V. All rights reserved.

\section{Introduction}

Synthetic natural gas (SNG) with high heating value from coal gasification has attracted intense attention as a result of the growing demand for natural gas as an energy carrier as well as the desire for clean utilization of coal resource [1-4]. However, during the SNG production, the $\mathrm{CO}$ methanation step, expressed by the equation $3 \mathrm{H}_{2}+\mathrm{CO} \rightarrow \mathrm{CH}_{4}+\mathrm{H}_{2} \mathrm{O}$, is associated with a highly exothermic process and thus leads to serious deactivation of catalysts [5]. Therefore, extensive efforts have been devoted to develop high-performance catalysts, which should show high catalytic activity at low temperature while retain excellent catalytic stability against sintering and carbon deposition at high temperature for $\mathrm{CO}$ methanation. Among the catalysts being explored, precious metal-based catalysts such as $\mathrm{Ru}$ and $\mathrm{Rh}$ have been found to exhibit excellent catalytic performance for CO methanation at lower temperature [6-10]. Unfortunately, these precious metals are expensive and rare in resources, so they do not have the economic feasibility relative to the non-noble metals for large-scale commercial applications [11]. Among non-noble metal-based catalysts, Ni-based catalysts are regarded as the most promising materials for $\mathrm{CO}$ methanation owing to their low price and high abundance [12-16]. However, for traditional Ni-based catalysts, they are

\footnotetext{
* Corresponding author. Tel/Fax: +1-212-854-6166; E-mail: jgchen@columbia.edu

\# Corresponding author. Tel/Fax: +86-516-83883501; E-mail: xiangkunren@cumt.edu.cn

This work was supported by the Fundamental Research Funds for the Central Universities (2015XKMS061).

DOI: 10.1016/S1872-2067(17)62862-6 | http://www.sciencedirect.com/science/journal/18722067 | Chin. J. Catal., Vol. 38, No. 7, July 2017
} 
prone to be quickly deactivated resulting from the aggregation of Ni nanoparticles and the formation of coke on the surface of the catalysts at high temperature [17,18].

Recently, extensive investigations have been made to explore highly efficient Ni-based catalysts combining excellent catalytic performance and high catalytic stability using mesoporous silica sieves with high specific surface area and uniform mesoporous structure as the supports, such as SBA-15 [19-21] and MCM-41 [22-24]. As reported by Tao et al. [19], during CO methanation, Ni-based catalyst using SBA-15 as the support displayed superior catalytic performance due to the good dispersion of Ni nanoparticles. Moreover, it has been also reported that Ni-based catalyst supported on MCM- 41 for CO methanation possessed good catalytic activity, but Ni species were vulnerable to sintering after high temperature reduction and calcination [22]. Therefore, it is still a significant challenge to achieve excellent catalytic performance while hindering the coking and sintering of Ni nanoparticles.

Promoter often has a significant impact on catalytic performance by means of modifying active metal dispersion, crystallite size and thermal stability of the catalyst [18,25-30]. Consequently, it is a promising strategy to enhance the catalytic performance by incorporation of a proper promoter species. Liu et al. [25] investigated $\mathrm{Ni}-\mathrm{V}_{2} \mathrm{O}_{3} / \mathrm{Al}_{2} \mathrm{O}_{3}$ catalyst and revealed that the addition of $\mathrm{V}$ species facilitated the enhancement of catalytic activity due to larger $\mathrm{H}_{2}$ uptake and higher Ni dispersion. It has been also reported that for $\mathrm{Ni} / \gamma-\mathrm{Al}_{2} \mathrm{O}_{3}$ catalysts, doping of Ce species, promoted CO methanation due to high $\mathrm{Ni}$ dispersion and small Ni nanoparticles [26]. Furthermore, Zhi et al. [27] demonstrated that Ni-La/SiC possessed high catalytic activity and good catalytic stability, which were attributed to the formation of smaller Ni nanoparticles with high metal dispersion, the stronger interaction with the support resulting from the addition of La species. In addition, Mn species was reported to improve catalytic activity and stability due to the formation of relative small $\mathrm{Ni}$ nanoparticles [18]. It is well acknowledged that the rate-determining step for CO methanation was mainly associated with the hydrogenation of $\mathrm{CH}_{x}$ [31], and that small $\mathrm{Ni}$ nanoparticles with well-dispersed $\mathrm{Ni}$ are conducive to $\mathrm{CH}_{x}$ hydrogenation resulting from the increasing surface defects to capture more surface hydrogen for dissociation [32]. Based on the above-mentioned analysis, it is expected that these promoter species, namely $\mathrm{V}, \mathrm{Ce}, \mathrm{La}$, and $\mathrm{Mn}$, could have similar roles in the enhancement of catalytic performance for the Ni-based catalyst supported on various material for $\mathrm{CO}$ methanation. At present, 3D-mesoporous KIT-6 as a novel silica material with higher specific surface area and pore volume consists of two interwoven subnetworks [33,34], which are conducive to produce more active sites for enhancing catalytic performance. However, to date, it is still not fully understood how the catalytic activity and stability of Ni-based catalyst fixed inside 3D-mesoporous KIT- 6 are affected by various promoter species.

In the present work, our aim was to synthesize promoter-modified Ni-based catalysts for CO methanation using 3D-mesoporous KIT-6 as a support modified by ethylene glycol with an incipient-wetness impregnation method, and to further systematically explore the effect of promoter species on catalytic performance. The catalysts were characterized by $\mathrm{N}_{2}$ adsorption-desorption, X-ray diffraction (XRD), hydrogen temperature-programmed reduction $\left(\mathrm{H}_{2}\right.$-TPR), hydrogen temperature-programmed desorption ( $\mathrm{H}_{2}$-TPD), Fourier transformed infrared spectroscopy (FT-IR), transmission electron microscope (TEM), energy-dispersive X-ray spectroscopy (EDX), Raman, and thermal gravimetric analysis (TGA), respectively. Our characterization results revealed that promoter-modified catalysts possessed higher catalytic activity at low temperature relative to that of promoter-unmodified catalyst. Moreover, the catalyst modified by $\mathrm{V}$ species exhibited the best catalytic performance with superior stability, which was viewed as a promising candidate for CO methanation.

\section{Experimental}

\subsection{Catalyst preparation}

3D-mesoporous KIT-6 was synthesized based on the previously published method [35]. Typically, 4 g P123 was dissolved into $\mathrm{HCl}$ aqueous solution of $150 \mathrm{~mL}$ at $35{ }^{\circ} \mathrm{C}$ with vigorous stirring, followed by the addition of $4.9 \mathrm{~mL} 1$-butanol. Subsequently, silicon source TEOS ( $9.2 \mathrm{~mL}$ ) was dripped into the above solution and stirred continuously at $35^{\circ} \mathrm{C}$ for $24 \mathrm{~h}$. The resulting mixture was then aged at $100{ }^{\circ} \mathrm{C}$ for $24 \mathrm{~h}$. The solid product obtained by filtration, washing and drying was further calcined in air at $550^{\circ} \mathrm{C}$ for $4 \mathrm{~h}$ with a heating rate of 2 ${ }^{\circ} \mathrm{C} / \mathrm{min}$ for removing the structure directing agent to obtain 3D-mesoporous KIT-6. Next, 3D-mesoporous KIT-6 was pretreated with ethylene glycol using incipient-wetness impregnation prior to the impregnation of Ni precursor and statically kept for $1 \mathrm{~h}$ at room temperature. After drying for $12 \mathrm{~h}$ at 100 ${ }^{\circ} \mathrm{C}$, the modified 3D-mesoporous KIT- 6 as a support was dispersed in nickel nitrate aqueous solution of $10 \mathrm{wt} \% \mathrm{NiO}$ along with various promoters of $2 \mathrm{wt} \%$, including $\mathrm{V}, \mathrm{Ce}$, La and $\mathrm{Mn}$, for $10 \mathrm{~h}$ at $60{ }^{\circ} \mathrm{C}$ with stirring, and then stirred continuously to further remove the water. After that, the solid product was dried at $100{ }^{\circ} \mathrm{C}$ overnight and further calcinated at $550{ }^{\circ} \mathrm{C}$ for 4 $\mathrm{h}$ in a muffle furnace. The final product as a catalyst was named as Ni-M/KIT-6, where M represents promoter species. For comparison, a catalyst without promoter was prepared following the identical procedure, and noted as Ni/KIT-6.

\subsection{Catalyst characterization}

$\mathrm{N}_{2}$ adsorption-desorption isotherms at $-196{ }^{\circ} \mathrm{C}$ were investigated using a surface area and porosity analyzer (Micromeritics Tristar II 3000 analyzer). Before $\mathrm{N}_{2}$ adsorption measurement, these samples were initially outgassed at $100{ }^{\circ} \mathrm{C}$ for $1 \mathrm{~h}$ and then at $300{ }^{\circ} \mathrm{C}$ for $3 \mathrm{~h}$. The specific surface areas of the samples were calculated from $\mathrm{N}_{2}$ adsorption data using the Brunauer-Emmett-Teller (BET) method. The pore size of the sample was derived from the Barret-Joyner-Hallender (BJH) method based on $\mathrm{N}_{2}$ desorption branch. XRD patterns in the ranges of $10^{\circ}$ to $80^{\circ}$ and $0.5^{\circ}$ to $5^{\circ}$ were collected by a Rigaku D/MAX-2500 diffractometer. The scanning speed for the wide 
angle and small angle were $8^{\circ} / \mathrm{min}$ and $5^{\circ} / \mathrm{min}$, respectively. The mean size of Ni nanoparticles was estimated according to the Debye-Scherrer equation.

$\mathrm{H}_{2}$-TPR and $\mathrm{H}_{2}$-TPD were performed on a Micromeritics AutoChem 2910 system with a thermal conductivity detector (TCD). $\mathrm{H}_{2}$-TPR was investigated in a mixture gas flow of 30 $\mathrm{mL} / \mathrm{min}$ (10 vol\% $\mathrm{H}_{2} / \mathrm{Ar}$ ) using $50 \mathrm{mg}$ catalyst from room temperature to $800{ }^{\circ} \mathrm{C}$ with a ramping rate of $10{ }^{\circ} \mathrm{C} / \mathrm{min}$. For $\mathrm{H}_{2}$-TPD, $100 \mathrm{mg}$ catalyst was reduced in situ in a pure $\mathrm{H}_{2}$ flow of $30 \mathrm{~mL} / \mathrm{min}$ at $550{ }^{\circ} \mathrm{C}$ for $2 \mathrm{~h}$, and then cooled to $50{ }^{\circ} \mathrm{C}$. After removing weakly adsorbed hydrogen by purging with $\mathrm{Ar}$, the temperature was raised to $800{ }^{\circ} \mathrm{C}$ at a heating rate of 10 ${ }^{\circ} \mathrm{C} / \mathrm{min}$. The released $\mathrm{H}_{2}$ was further measured by the TCD, and the $\mathrm{H}_{2}$-TPD result was used to calculate the number of active $\mathrm{Ni}$ sites per unit mass with the assumption of an adsorption 1:1 stoichiometry of $\mathrm{H}$ to $\mathrm{Ni}$. The peak area of the $\mathrm{H}_{2}$-TPD curve was calibrated with a standard $\mathrm{CuO}$ sample. The Ni dispersion was determined by the simplified expression [36]:

$$
D(\%)=2 \times V_{\text {ad }} \times M \times S F \times 100 /\left(m \times P \times V_{\mathrm{m}} \times d_{\mathrm{r}}\right)
$$

where $V_{\text {ad }}(\mathrm{mL})$ represents the chemisorbed $\mathrm{H}_{2}$ volume derived from the TPD test under standard temperature and pressure (STP); $M$ is the mole mass of $\mathrm{Ni}(58.69 \mathrm{~g} / \mathrm{mol})$ and $m$ is the mass of the catalyst sample (g); $S F$ is the stoichiometric factor (the Ni/H molar ratio for chemisorption), which is defined as 1 ; $P$ is the Ni mass percentage of the sample and $V_{\mathrm{m}}$ is the molar volume of $\mathrm{H}_{2}(22414 \mathrm{~mL} / \mathrm{mol})$ at STP; $d_{\mathrm{r}}$ is the degree of reduction from $\mathrm{Ni}$ species calculated by $\mathrm{H}_{2}$-TPR.

FT-IR spectra were recorded within the wavenumber region from 400 to $4000 \mathrm{~cm}^{-1}$. The morphology of the sample was investigated by TEM equipped with EDX using a Philips TECNAI G2F20 instrument at $200 \mathrm{kV}$. Before the measurement, the analytic sample was dispersed into the ethanol with ultrasonic stirring to obtain uniform suspension. A drop of the resulting suspension was then deposited on a holey carbon-supported grid. Raman spectra data in the range of $200-1400 \mathrm{~cm}^{-1}$ were recorded by a Renishaw inVia Raman spectrometer using an argon ion laser with a wavelength of $514.5 \mathrm{~nm}$. TGA was conducted by a STA449F3 (NETZSCH Corp.) under an air flow of $80 \mathrm{~mL} / \mathrm{min}$ within a temperature range from room tempera-

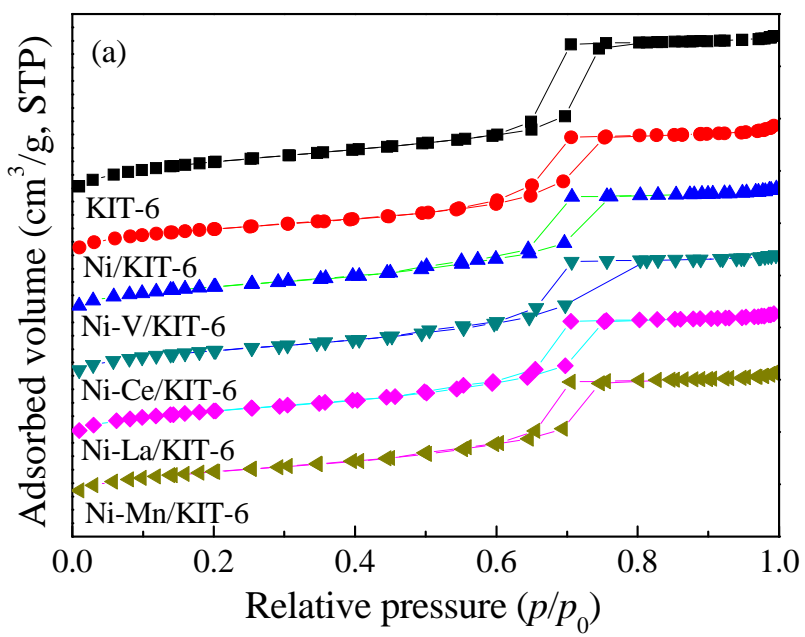

ture to $800^{\circ} \mathrm{C}$ at a ramping rate of $10^{\circ} \mathrm{C} / \mathrm{min}$.

\subsection{Catalytic performance}

CO methanation was conducted in the continuous flow fixed-bed reactor with a quartz tube of inner diameter $6 \mathrm{~mm}$ at 250-400 ${ }^{\circ} \mathrm{C}$ and $1 \mathrm{~atm}$. For each test, $50 \mathrm{mg}$ catalyst (40-60 mesh) mixed with $500 \mathrm{mg}$ quartz sand (40-60 mesh) homogenously was filled in the quartz tube, and a thermocouple was located in the center of reaction temperature zone to detect temperature. Prior to the performance test, the catalyst was reduced in situ in $40 \mathrm{~mL} / \mathrm{min}$ gas flow of $50 \mathrm{vol} \% \mathrm{H}_{2} / \mathrm{N}_{2}$ mixture at $550{ }^{\circ} \mathrm{C}$ for $2 \mathrm{~h}$. After cooling down to the initial reaction temperature in $\mathrm{N}_{2}$, the mixed reactant gas with a mole ratio $\mathrm{H}_{2}: \mathrm{CO}: \mathrm{N}_{2}=3: 1: 1$ and a total flow rate of $50 \mathrm{~mL} / \mathrm{min}$ was fed into the reactor accompanied by a weight hourly space velocity (WHSV) of $60000 \mathrm{~mL} /(\mathrm{g} \cdot \mathrm{h}$ ). The outlet gas was cooled by a cold trap to remove any water, and then analyzed on-line by gas chromatograph (GC-SP2100, China) equipped with a TDX-01 and a TCD with Ar as the carrier gas. The $60 \mathrm{~h}$-lifetime test for $\mathrm{CO}$ methanation was carried out at atmospheric pressure and $500{ }^{\circ} \mathrm{C}$ with a WHSV of $60000 \mathrm{~mL} / \mathrm{g} \cdot \mathrm{h})$. The calculation formulas for CO conversion, $\mathrm{CH}_{4}$ selectivity and $\mathrm{CH}_{4}$ yield, were defined as the follows:

$$
\begin{gathered}
\mathrm{CO} \text { conversion (\%) = } 100 \times\left(V_{\mathrm{CO}, \text { in }}-V_{\mathrm{CO}, \text { out }}\right) / V_{\mathrm{CO}, \text { in }} \\
\mathrm{CH}_{4} \text { selectivity }(\%)=100 \times V_{\mathrm{CH} 4 \text { out }} /\left(V_{\mathrm{CO}, \text { in }}-V_{\mathrm{CO}, \text { out }}\right) \\
\mathrm{CH}_{4} \text { yield (\%) }=100 \times V_{\mathrm{CH} 4, \text { out }} / V_{\mathrm{CO}, \text { in }}
\end{gathered}
$$

where $V_{\mathrm{i}, \text { in }}$ and $V_{\mathrm{i}, \text { out }}$ represent the volume flow rate of species $\mathrm{i}$ $\left(\mathrm{CO}, \mathrm{CH}_{4}\right)$ at the inlet and outlet, respectively.

\section{Results and discussion}

\subsection{Catalyst characterization}

\subsection{1. $\mathrm{N}_{2}$ adsorption-desorption}

Fig. 1 displayed $\mathrm{N}_{2}$ adsorption-desorption isotherms and the corresponding pore size distribution curves of 3D-mesoporous KIT- 6 and the catalysts. As seen from Fig. 1(a), $\mathrm{N}_{2}$ adsorption-desorption isotherms of all samples were in line with typ-

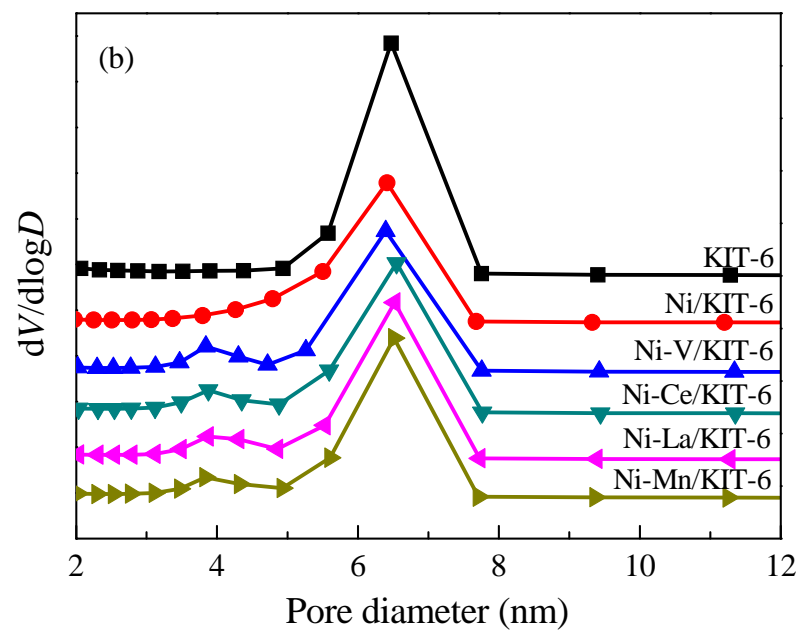

Fig. 1. $\mathrm{N}_{2}$ adsorption-desorption isotherms (a) and the corresponding pore size distribution curves (b) of KIT-6, Ni/KIT-6 and promoter-modified catalysts. 
Table 1

Physicochemical properties of KIT- 6 and catalysts.

\begin{tabular}{|c|c|c|c|c|c|c|}
\hline Catalyst & $A_{\mathrm{BET}}{ }^{\mathrm{a}}\left(\mathrm{m}^{2} / \mathrm{g}\right)$ & $V_{\mathrm{p}}{ }^{\mathrm{b}}\left(\mathrm{cm}^{3} / \mathrm{g}\right)$ & $D_{\mathrm{p}}{ }^{\mathrm{c}}(\mathrm{nm})$ & Ni nanoparticle size $d_{\mathrm{Ni}}{ }^{\mathrm{d}}(\mathrm{nm})$ & $\mathrm{H}_{2}$ uptake $(\mu \mathrm{mol} / \mathrm{g})$ & $D^{\mathrm{e}}(\%)$ \\
\hline KIT-6 & 722.7 & 1.07 & 5.84 & - & - & - \\
\hline $\mathrm{Ni} / \mathrm{KIT}-6$ & 551.3 & 0.86 & 5.77 & 2.4 & 106.0 & 15.8 \\
\hline Ni-V/KIT-6 & 580.6 & 0.84 & 5.48 & 1.9 & 177.6 & 26.5 \\
\hline $\mathrm{Ni}-\mathrm{Ce} / \mathrm{KIT}-6$ & 584.0 & 0.83 & 5.43 & 2.0 & 145.0 & 21.6 \\
\hline Ni-La/KIT-6 & 587.6 & 0.84 & 5.46 & 2.3 & 146.5 & 21.9 \\
\hline Ni-Mn/KIT-6 & 572.7 & 0.84 & 5.59 & 2.3 & 132.8 & 19.8 \\
\hline Spent Ni/KIT-6 & - & - & - & 5.8 & - & - \\
\hline Spent Ni-V/KIT-6 & - & - & - & 2.7 & - & - \\
\hline
\end{tabular}

a Surface areas of the catalysts based on the BET equation;

b Pore volumes of the catalysts derived from the volume of $\mathrm{N}_{2}$ adsorbed at $p / p_{0}=0.97$;

c Average pore sizes calculated by the BJH method using the desorption branch;

d Ni nanoparticle size estimated from Ni(111) plane using the Debye-Scherrer equation;

e Ni dispersion determinated by the $\mathrm{H}_{2}$-TPR and $\mathrm{H}_{2}$-TPD.

ical IV type isotherms, with an H1 hysteresis loop [37] and a steep capillary condensation step between $p / p_{0}=0.6-0.8$, which were characteristic of large channel-like pores with a narrow range of size [38,39]. The shapes of the isotherms and hysteresis loops of all catalysts were the same as those of 3D-mesoporous KIT-6, meaning that 3D-mesopores were still maintained after incorporation of various metal species [40]. Fig. 1(b) displayed bimodal pore size distributions for promoter-modified catalysts, corresponding to the small-size aperture at around $4 \mathrm{~nm}$ and large-size aperture at around $6.5 \mathrm{~nm}$, while 3D-mesoporous KIT- 6 and Ni/KIT-6 showed monomodal pore size distributions with an aperture of about $6.5 \mathrm{~nm}$. Moreover, the physicochemical properties of all samples were summarized in Table 1. It was clearly seen that 3D-mesoporous KIT-6 possessed the largest specific surface area, the highest pore size and pore volume, which were $722.7 \mathrm{~m}^{2} / \mathrm{g}, 5.84 \mathrm{~nm}$ and 1.07 $\mathrm{cm}^{3} / \mathrm{g}$, respectively, indicating that 3D-mesoporous KIT-6 was quite suitable as a support for $\mathrm{CO}$ methanation. By comparison with 3D-mesoporous KIT-6, the BET surface area, pore size and pore volume for all catalysts exhibited significant decrease due to loading of active metal $\mathrm{Ni}$ or/and promoter species into 3D-mesopores. Interestingly, there was a slight increase in the surface area of promoter-modified catalyst compared to that of Ni/KIT-6, which was caused by the fact that some promoter species introduced into 3D-mesopores resulted in an increase of surface roughness. However, the average pore sizes and pore volumes of promoter-modified catalysts showed marked de- crease relative to $\mathrm{Ni} / \mathrm{KIT}-6$, reflecting that both promoter species and active metal $\mathrm{Ni}$ were successfully introduced into 3D-mesopores, which were consistent with bimodal pore size distributions, corresponding to the effective confinement effect of 3D-mesopores.

\subsubsection{XRD measurement}

Fig. 2(a) and (b) displayed low-angle XRD patterns of 3D-mesoporous KIT-6 as a support and Ni-V/KIT-6. 3D-mesoporous KIT- 6 showed characteristic diffraction peaks of 3D-mesopores with a cubic Ia3d space group, corresponding to the (211) $\left(2 \theta=0.97^{\circ}\right)$ and $(220)\left(2 \theta=1.10^{\circ}\right)$ planes, respectively [41]. It can be seen that 3D-mesoporous KIT-6 and Ni-V/KIT-6 exhibited similar characteristic peaks, which suggested that 3D-mesopores was still maintained after the addition of active metal $\mathrm{Ni}$ and promoter species $\mathrm{V}$. This was in good agreement with the result on $\mathrm{N}_{2}$ adsorption-desorption isotherms. Moreover, wide-angle XRD patterns of all catalysts were also showed in Fig. 2(c). For all catalysts, the faint characteristic diffraction peaks observed at $2 \theta=44.3^{\circ}$ were indexed as the (111) plane of face centered cubic Ni [19], implying the formation of small Ni nanoparticles. Ni nanoparticle sizes of all catalysts estimated from XRD were listed in Table 1. For promoter-modified catalysts, the mean sizes of $\mathrm{Ni}$ nanoparticles were almost the same as that of Ni/KIT-6, suggesting that the formation of fine Ni nanoparticles was due to the effective confinement effect of 3D-mesopores. In addition, the absence of
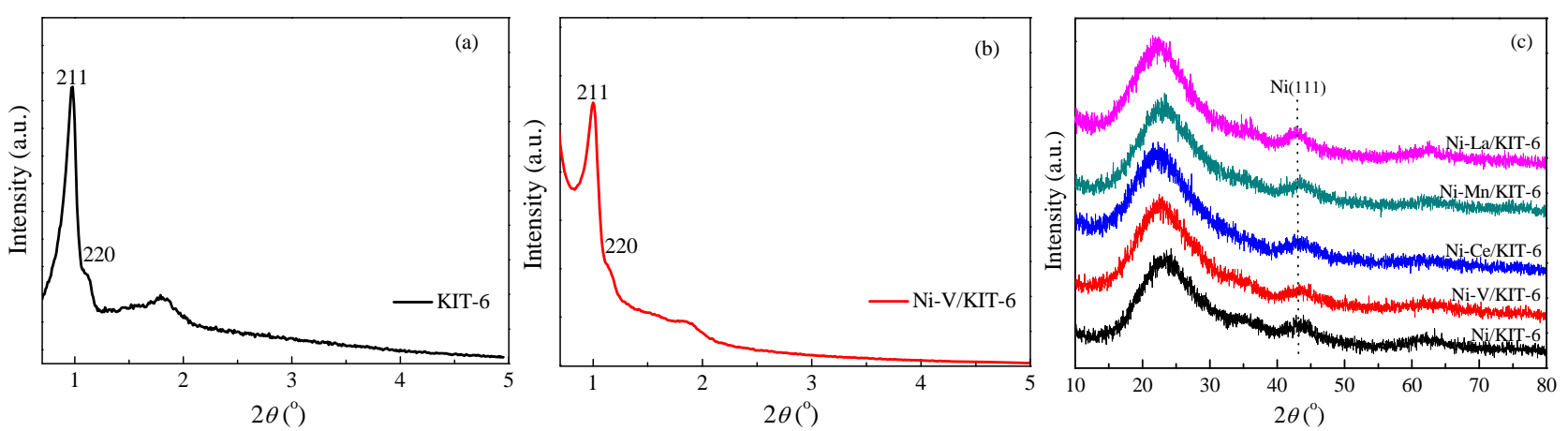

Fig. 2. Low-angle XRD patterns of (a) KIT-6 and (b)Ni-V/KIT-6; (c) Wide-angle XRD patterns of Ni/KIT-6 and promoter-modified catalysts. 
any diffraction peaks associated with the promoter species demonstrated that the promoter species were highly dispersed on 3D-mesoporous KIT-6 as a support.

\subsection{3. $H_{2}$-TPR analysis}

As seen from Fig. 3, the unmodified 3D-mesoporous KIT-6 did not show any reduction peaks in the temperature range from 100 to $800{ }^{\circ} \mathrm{C}$, which implied that all the hydrogen consumption peaks for other samples belonged to the reduction of $\mathrm{NiO}$. The $\mathrm{H}_{2}$-TPR profiles were fitted using the Gaussian fitting method; for Ni/KIT-6, there were three distinct reduction peaks located at around 349,397 and $522^{\circ} \mathrm{C}$, respectively. The low-temperature peak at around $349^{\circ} \mathrm{C}$ was derived from the reduction of $\mathrm{NiO}$, which showed a weak contact with 3D-mesoporous KIT-6 [42]. The mid-temperature peak at around $397{ }^{\circ} \mathrm{C}$ originated from the reduction of bulk $\mathrm{NiO}$ interacting moderately with 3D-mesoporous KIT-6. The high-temperature peak at around $522{ }^{\circ} \mathrm{C}$ corresponded to the existence of $\mathrm{Ni}$ silicate or small $\mathrm{NiO}$ nanoparticles, implying that an intimate interaction occurred between $\mathrm{NiO}$ and 3D-mesoporous KIT-6 [43]. In comparison, all reduction peaks of Ni-Mn/KIT-6 displayed a slight shift to lower temperature relative to that of $\mathrm{Ni} / \mathrm{KIT}-6$, which was indicative of relatively poor metal-support interaction, suggesting that loading of $\mathrm{Mn}$ species was of benefit to produce some more easily reducible species. Apparently, Ni-La/KIT- 6 and Ni-Ce/KIT- 6 were similar in both shape and position of the reduction peaks, which were broader and shifted to higher temperature (high-temperature peaks extended to $670{ }^{\circ} \mathrm{C}$ ) relative to that of Ni/KIT-6, suggesting a stronger interaction with 3D-mesoporous KIT- 6 due to the addition of promoter species. For Ni-V/KIT-6, the intensity of the low-temperature peak decreased sharply while the intensity of the high-temperature peak increased remarkably to become the main reduction peak at around $532{ }^{\circ} \mathrm{C}$. Based on the increase in the total $\mathrm{H}_{2}$-TPR area, an intimate interaction between active metal and support resulted in an improved reducibility of $\mathrm{NiO}$. From the fitting results, we have made a quantitative analysis based on the integrated area below 550

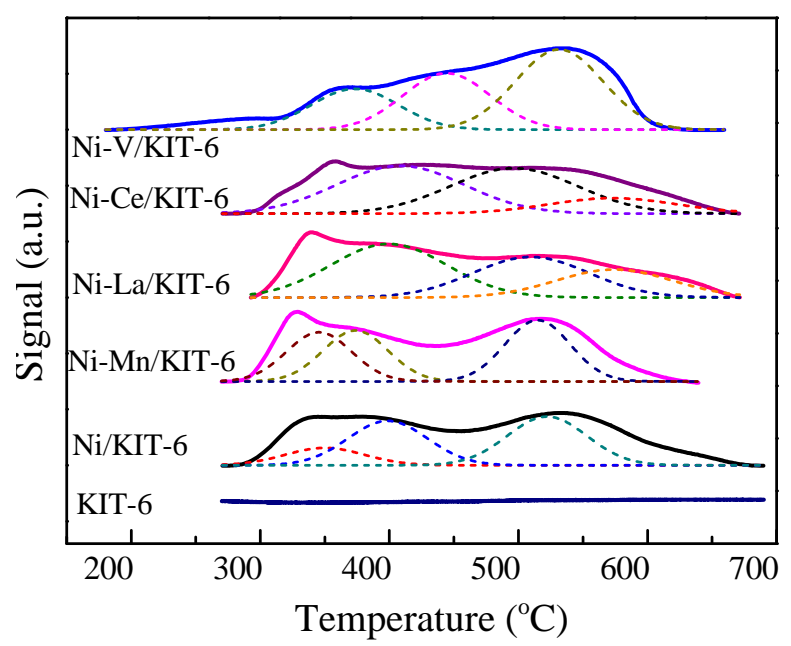

Fig. 3. $\mathrm{H}_{2}-\mathrm{TPR}$ profiles of KIT-6, Ni/KIT-6 and promoter-modified catalysts.
Table 2

$\mathrm{H}_{2}$-TPR quantitative data of the catalysts.

\begin{tabular}{|c|c|c|c|c|c|c|c|}
\hline \multirow{2}{*}{ Catalyst } & \multicolumn{3}{|c|}{ Temperature $\left({ }^{\circ} \mathrm{C}\right)$} & \multicolumn{3}{|c|}{ Integrated area } & \multirow{2}{*}{$\begin{array}{c}\text { Reducibility } \\
(\%)\end{array}$} \\
\hline & I & II & III & I & II & III & \\
\hline Ni/KIT-6 & 349 & 397 & 522 & 0.48 & 1.22 & 1.34 & 56.6 \\
\hline $\mathrm{Ni}-\mathrm{V} / \mathrm{KIT}-6$ & 373 & 444 & 532 & 1.24 & 1.71 & 2.43 & 1.0 \\
\hline Ni-Ce/KIT-6 & 408 & 496 & 574 & 2.10 & 2.00 & 0.66 & 76.4 \\
\hline Ni-La/KIT-6 & 399 & 495 & 575 & 2.14 & 1.63 & 1.11 & 70.2 \\
\hline Ni-Mn/KIT-6 & 345 & 373 & 513 & 1.11 & 1.15 & 1.38 & 67.7 \\
\hline
\end{tabular}

I: Low-temperature peak of $\mathrm{H}_{2}$-TPR; II: Mid-temperature peak of $\mathrm{H}_{2}$-TPR; III: High-temperature peak of $\mathrm{H}_{2}$-TPR.

* Reducibility estimated by: $\left(A_{\mathrm{I}}+A_{\mathrm{II}}+A_{\mathrm{III}}\right) /\left(A_{\mathrm{I}}+A_{\mathrm{II}}+A_{\mathrm{III}}\right)_{\mathrm{Ni}-\mathrm{V} / \mathrm{KIT}-6} \times 100 \%$, especially reducibility of Ni-Ce/KIT- 6 and Ni-La/KIT- 6 estimated by: $\left(A_{\mathrm{I}}\right.$ $\left.+A_{\mathrm{II}}\right) /\left(A_{\mathrm{I}}+A_{\mathrm{II}}+A_{\mathrm{III}}\right)_{\mathrm{Ni}-\mathrm{V} / \mathrm{KIT}-6} \times 100 \%$.

${ }^{\circ} \mathrm{C}$, which was the reduction temperature used in this study. As compared in Table 2, Ni-V/KIT-6 possessed the largest total integrated area with three different reduction peaks below 550 ${ }^{\circ} \mathrm{C}$, hence its reducibility was defined as $100 \%$. The relative reducibility of the other catalysts was calculated from the ratio of its total integrated area with reduction peak below $550{ }^{\circ} \mathrm{C}$ relative to that of Ni-V/KIT-6. Based on the relative reducibility values, all promoter-modified catalysts exhibited higher reducibility than Ni/KIT-6, with Ni-V/KIT-6 showing the highest reducibility.

\subsection{4. $H_{2}$-TPD analysis}

Fig. 4 presented $\mathrm{H}_{2}$-TPD profiles of all catalysts to estimate the hydrogen uptake and $\mathrm{Ni}$ dispersion. It was apparent that there were two major $\mathrm{H}_{2}$ desorption peaks in the test temperature range, which were attributed to low-temperature peaks at less than $500{ }^{\circ} \mathrm{C}$ and high-temperature peaks at around 700 ${ }^{\circ} \mathrm{C}$. $\mathrm{H}_{2}$ desorption peaks at low temperature corresponded to the weakly adsorbing hydrogen on the surface of highly dispersed Ni with a large density of surface defects, which acted as hydrogen capture agent [31]. $\mathrm{H}_{2}$ desorption peaks at high temperature arose from strongly adsorbing and/or spillovered hydrogen [44], and exhibited almost no variation in peak position and integrated area for all catalysts. The

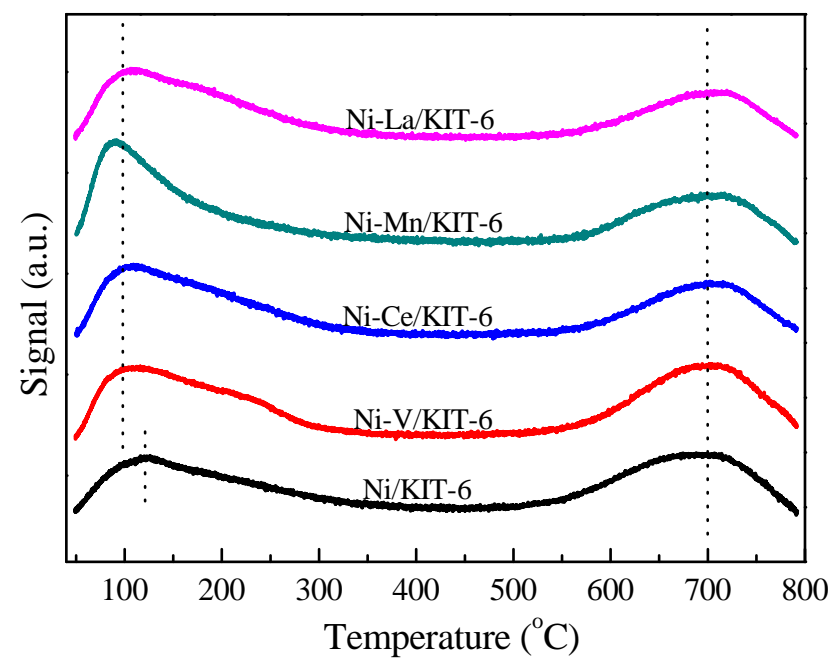

Fig. 4. $\mathrm{H}_{2}$-TPD profiles of Ni/KIT- 6 and promoter-modified catalysts. 
integrated areas of low-temperature $\mathrm{H}_{2}$ desorption peaks were substantially different for the catalysts with different promoter species. Ni-V/KIT-6 possessed the largest integrated area, suggesting that $\mathrm{V}$ species most effectively facilitated $\mathrm{Ni}$ dispersion. $\mathrm{H}_{2}$-uptakes and $\mathrm{Ni}$ dispersion for all catalysts were summarized in Table 1 . Among these catalysts, Ni-V/KIT-6 showed a maximum $\mathrm{H}_{2}$ uptake of $177.6 \mu \mathrm{mol} / \mathrm{g}$ and Ni dispersion of $26.5 \%$, corresponding to the strongest $\mathrm{H}_{2}$ adsorption capacity and the highest $\mathrm{Ni}$ dispersion. The explanation was that $V$ species was contributed to the enhancement of hydrogen storage and mobility, ultimately leading to the enhanced catalytic performance. Noting that, both Ni-Ce/KIT-6 and Ni-La/KIT-6 showed a pronounced increase in the low-temperature peak as compared with Ni/KIT-6, implying better $\mathrm{Ni}$ dispersion which corresponded to $\mathrm{Ni}$ dispersion of $21.6 \%$ and $21.9 \%$, respectively. Additionally, Ni-Mn/KIT-6 displayed the lowest $\mathrm{Ni}$ dispersion of $19.8 \%$ as compared to that of other promoter-modified catalysts, which was caused by the smallest integrated area of the low-temperature $\mathrm{H}_{2}$ desorption peak, but still larger than Ni dispersion of Ni/KIT-6 (15.8\%), meaning that Mn species likewise played a role in the enhancement of $\mathrm{Ni}$ dispersion.

\subsubsection{FT-IR spectroscopy}

FT-IR spectra of all samples were illustrated in Fig. 5. There were four typical Si-O-Si bands centered at 464, 804, 965 and $1076 \mathrm{~cm}^{-1}$, which were related to the formation of condensed silica framework. The absorption peak at $464 \mathrm{~cm}^{-1}$ was derived from the bending vibrations of $\mathrm{Si}-\mathrm{O}-\mathrm{Si}$ bonds, while the broad absorption peaks at $1076 \mathrm{~cm}^{-1}$ and weak absorption peaks at $804 \mathrm{~cm}^{-1}$ were associated with symmetric and asymmetric stretching vibrations of $\mathrm{Si}-\mathrm{O}-\mathrm{Si}$ networks, respectively [45]. The absorption peaks corresponding to asymmetric stretching vibrations of $\mathrm{Si}-\mathrm{OH}$ bonds were observed at $965 \mathrm{~cm}^{-1}$. For all catalysts, the absorption peaks at $1076 \mathrm{~cm}^{-1}$ displayed a slight shift to lower wavenumbers as compared to that of unmodified 3D-mesoporous KIT-6, which was taken as an indication of $\mathrm{Ni}$

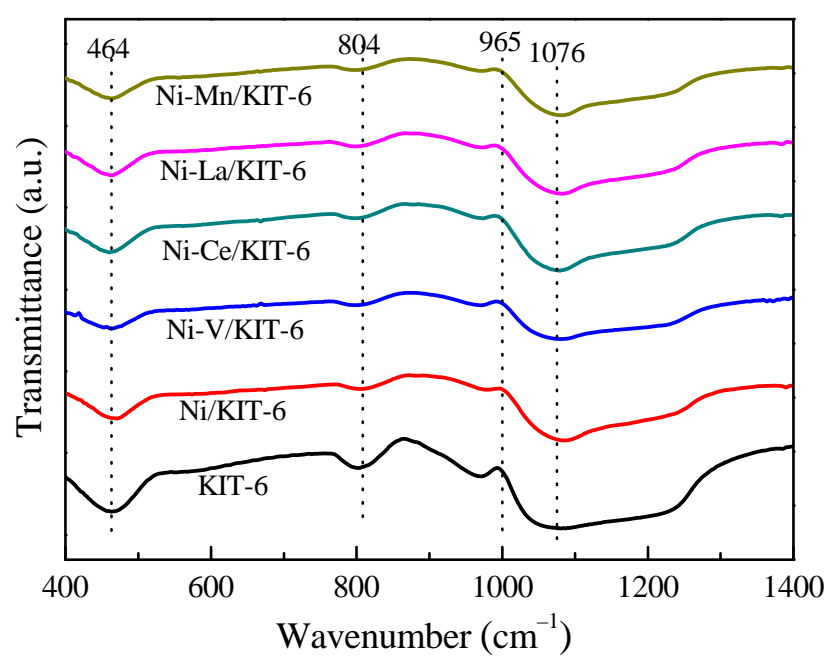

Fig. 5. FT-IR spectra of KIT-6, Ni/KIT-6 and promoter-modified catalysts.

and promoter species incorporated into 3D-mesopores. Moreover, the intensities of the absorption peaks at $965 \mathrm{~cm}^{-1}$ showed a slight decrease corresponding to the structural change of silanol group on the surface after introducing $\mathrm{Ni}$ and promoter species, indicating that silanol groups were partly converted to Si-0-M (V [46], Ce [47], La [48], or Mn [49]).

\subsubsection{TEM results}

TEM images of 3D-mesoporous KIT- 6 and all catalysts were displayed in Fig. 6. It can be seen that 3D-mesoporous KIT-6 presented highly-ordered cubic 3D-mesoporous channels, in good agreement with the observation of well-defined (211) and (220) planes in the low-angle XRD pattern as well as $\mathrm{N}_{2}$ adsorption-desorption isotherm. After the incorporation of $\mathrm{Ni}$ and promoter species, 3D-mesoporous channels were still regular and uniform, suggesting that the addition of metal species did not destroy 3D-mesopores, as shown in Fig. 6(B-F). Moreover, the dark spots given by Fig. $6\left(B^{\prime}-F^{\prime}\right)$ representing Ni nanoparti-

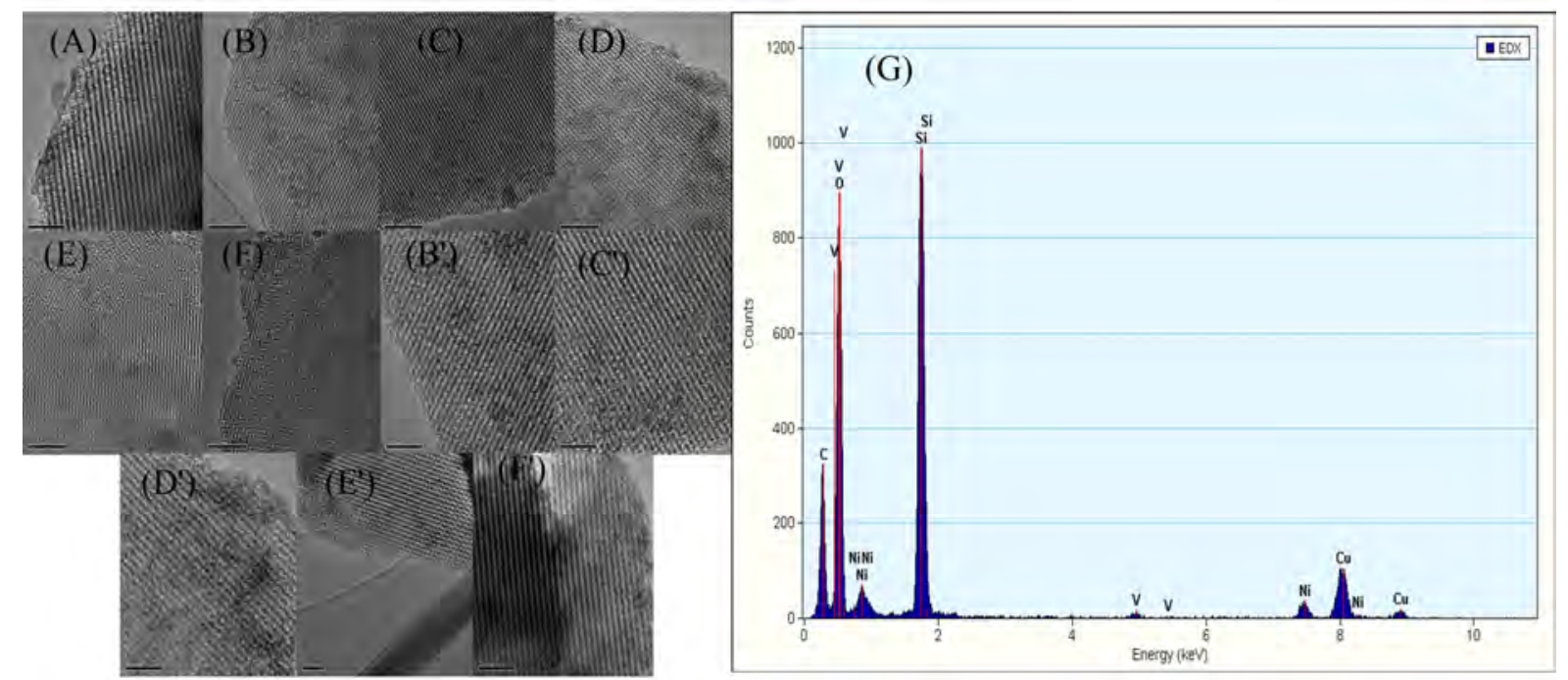

Fig. 6. TEM images of KIT-6 (A), Ni/KIT-6 (B, B'), Ni-V/KIT-6 (C, C'), Ni-Ce/KIT-6 (D, D'), Ni-La/KIT-6 (E, E'), Ni-Mn/KIT-6 (F, F'); (G) EDX profile of Ni-V/KIT-6. 
cles on the catalysts were evenly anchored over the internal surface of 3D-mesopores with a nanoparticle size of rough 2 3 $\mathrm{nm}$ that was less than the average pore size, meaning highly dispersion of Ni nanoparticles. However, there was no obvious observation of promoter species in all promoter-modified catalysts, which was caused by highly dispersion of promoter species. This was consistent with the result of XRD, and further proven by EDX profile, as shown in Fig. 6(G). It was noted that these elements, namely $\mathrm{Ni}, \mathrm{V}, \mathrm{Si}$ and $\mathrm{O}$, were observed in EDX spectrum, reflecting the successful introduction of these elements into 3D-mesopores of Ni-V/KIT-6. Furthermore, TEM analysis confirmed that both $\mathrm{Ni}$ and $\mathrm{V}$ species were highly dispersed into 3D-mesopores, leading to the generation of small Ni nanoparticles. Similarly, other promoters were also well dispersed into 3D-mesopores and played a critical role in enhancing catalytic activity and stabilizing $\mathrm{Ni}$ nanoparticles, as described next.

\subsection{Catalytic performance for CO methanation}

In order to explore the effect of promoter species on catalytic performance, CO methanation reactions from 250 to 400 ${ }^{\circ} \mathrm{C}$ over Ni/KIT- 6 and all promoter-modified catalysts were performed at $1 \mathrm{~atm}$ with a WHSV of $60000 \mathrm{~mL} / \mathrm{g} \cdot \mathrm{h})$, and the results were described in Fig. 7. For Ni/KIT-6, both CO conversion and $\mathrm{CH}_{4}$ yield were relatively poor below $325{ }^{\circ} \mathrm{C}$, and $\mathrm{CO}$ conversion achieved the maximum value of $93 \%$ when the temperature rose to $400{ }^{\circ} \mathrm{C}$. Comparing with $\mathrm{Ni} / \mathrm{KIT}-6$, the addition of promoter species enhanced the low-temperature catalytic activities and the thermodynamics equilibrium for $\mathrm{CO}$ conversion was reached between 325 and $400{ }^{\circ} \mathrm{C}$. Ni-V/KIT- 6 possessed the best catalytic performance at the entire reaction temperature range, and its maximal $\mathrm{CO}$ conversion and $\mathrm{CH}_{4}$ yield reached $100 \%$ and $85 \%$, respectively, at a relatively low reaction temperature of $350{ }^{\circ} \mathrm{C}$. Similarly, Ni-Ce/KIT-6, Ni-La/KIT-6 and Ni-Mn /KIT-6 also showed better catalytic activities with $\mathrm{CO}$ conversion of around $97 \%$ and $\mathrm{CH}_{4}$ yield of rough $75 \%$ at $350{ }^{\circ} \mathrm{C}$, while the corresponding CO conversion and $\mathrm{CH}_{4}$ yield over Ni/KIT- 6 were $33 \%$ and $29 \%$, respectively, at the same reaction temperature. Therefore, the addition of promoter species could substantially boost the low-temperature catalytic activity, and V species displayed the best promoter effect. Based on the characterization results discussed earlier, the superior catalytic performance for
Ni-V/KIT- 6 could be explained by the largest $\mathrm{H}_{2}$ uptakes (177.6 $\mu \mathrm{mol} / \mathrm{g}$ ), highest dispersion of $\mathrm{Ni}$ nanoparticles $(26.5 \%)$, the favorable reducibility of $\mathrm{NiO}$ for the generation of the most $\mathrm{Ni}$ active sites. Furthermore, the formation of the Si-O-V linkage, as described next with Raman results, as well as an enhanced confinement effect of 3D-mesopores were favorable to the generation of small Ni nanoparticles and high dispersion of $\mathrm{Ni}$ nanoparticles, thereby leading to the enhanced catalytic performance with good high-temperature stability. In addition, Ni-Ce/KIT-6 and Ni-La/KIT-6 showed better catalytic activity than that of Ni/KIT- 6 at temperature below $350{ }^{\circ} \mathrm{C}$, which was mainly due to their larger $\mathrm{H}_{2}$ uptakes and better $\mathrm{Ni}$ dispersion accompanied by a strong metal-support interaction. The addition of $\mathrm{Mn}$ as a promoter also improved the catalytic performance relative to that of Ni/KIT-6, which was attributed to high dispersion of Ni nanoparticles. Additionally, $\mathrm{CH}_{4}$ selectivity of all catalysts with various promoters remained relatively steady than that of Ni/KIT- 6 at above $325{ }^{\circ} \mathrm{C}$, indicating that the promoter species also played an important role in inhibiting the occurrence of some side reactions, such as the water-gas shift reaction $\left(\mathrm{CO}+\mathrm{H}_{2} \mathrm{O} \rightarrow \mathrm{CO}_{2}+\mathrm{H}_{2}\right)$ as well as the reversed $\mathrm{CH}_{4}$ and $\mathrm{CO}_{2}$ reforming reaction $\left(2 \mathrm{CO}+2 \mathrm{H}_{2} \rightarrow \mathrm{CO}_{2}+\mathrm{CH}_{4}\right)$, which would result in a lower $\mathrm{CH}_{4}$ selectivity. Overall, promoter-modified catalysts possessed better catalytic activity as compared with Ni/KIT-6, and Ni-V/KIT- 6 exhibited the best catalytic performance for $\mathrm{CO}$ methanation among all catalysts.

\subsection{Catalytic stability}

Lifetime test was very important in acquiring excellent catalyst during CO methanation with higher catalytic activity and better catalytic stability under severe reaction condition. Therefore, a lifetime test for Ni-V/KIT- 6 was conducted at 500 ${ }^{\circ} \mathrm{C}, 1 \mathrm{~atm}$ and a WHSV of $60000 \mathrm{~mL} /(\mathrm{g} \cdot \mathrm{h})$. Ni/KIT- 6 was also evaluated with the identical condition as a comparison. As shown in Fig. 8, there were nearly no change during the entire 60h-lifetime test for $\mathrm{CO}$ conversion, $\mathrm{CH}_{4}$ selectivity and $\mathrm{CH}_{4}$ yield of Ni-V/KIT-6, corresponding to $93 \%, 78 \%$ and $73 \%$, respectively. In comparison, Ni/KIT-6 displayed an obvious drop, with corresponding $\mathrm{CO}$ conversion of $90 \%, \mathrm{CH}_{4}$ selectivity of $74 \%$ and $\mathrm{CH}_{4}$ yield of $67 \%$, suggesting that Ni-V/KIT-6 possessed higher catalytic activity and better catalytic stability at high temperature.

To further understand the relationship between structure
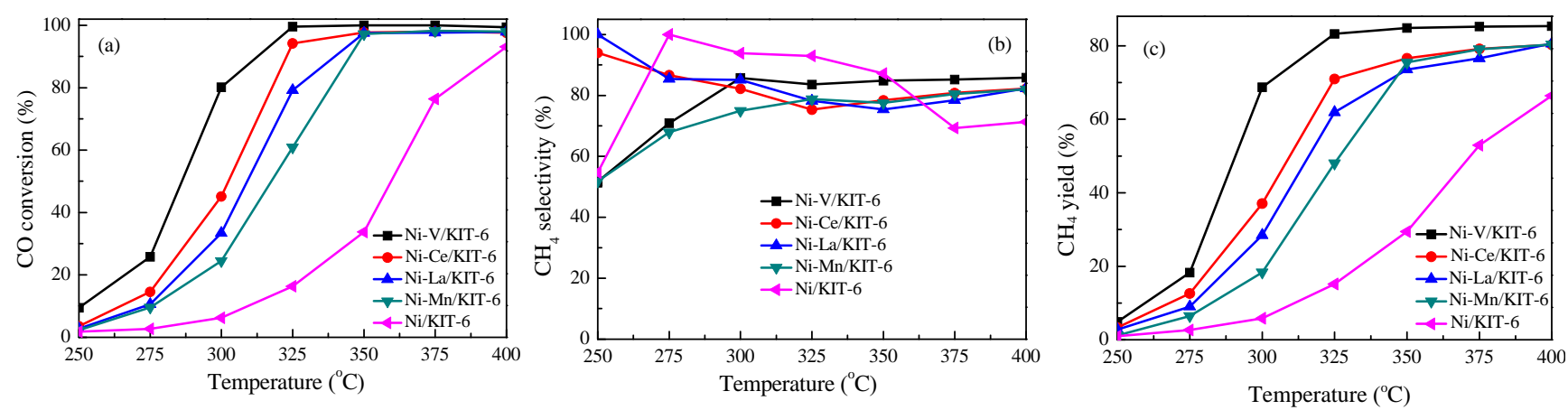

Fig. 7. Catalytic performance over Ni/KIT-6 and promoter-modified catalysts for $\mathrm{CO}$ methanation. (a) $\mathrm{CO}$ conversion; (b) $\mathrm{CH}_{4}$ selectivity; (c) $\mathrm{CH}_{4}$ yield. 

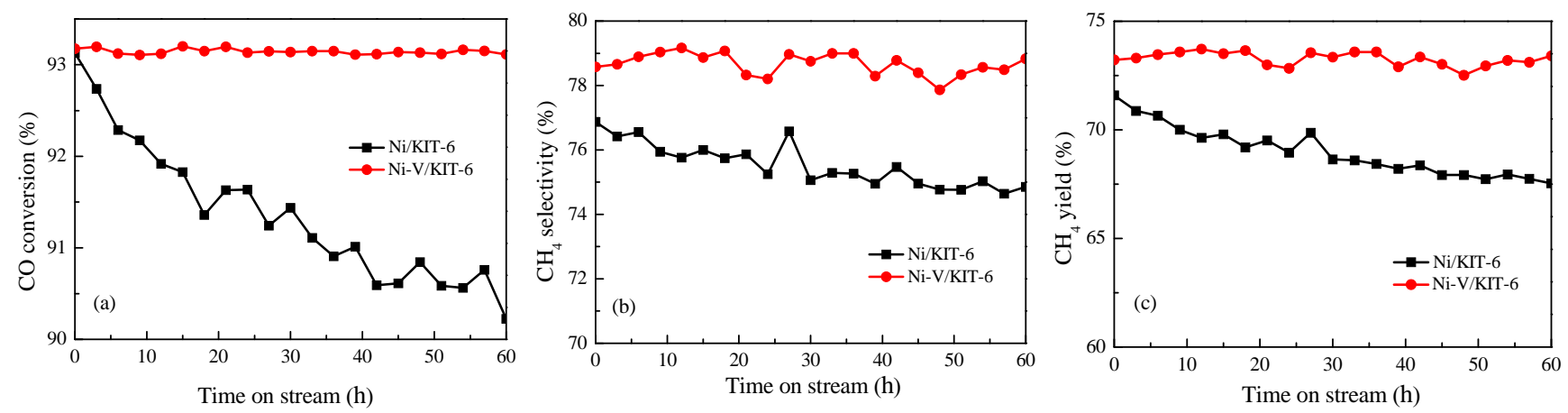

Fig. 8. Catalytic stability test of Ni/KIT-6 and Ni-V/KIT-6. (a) CO conversion; (b) $\mathrm{CH}_{4}$ selectivity; (c) $\mathrm{CH}_{4}$ yield.

and performance, Ni/KIT-6 and Ni-V/KIT-6 were characterized by Raman, and the results were displayed in Fig. 9. For $\mathrm{Ni} / \mathrm{KIT}-6$, two characteristic bands were observed at 485 and $970 \mathrm{~cm}^{-1}$, which arose from the symmetric and antisymmetric stretching of the $\mathrm{Si}-\mathrm{O}-\mathrm{Si}$ vibrations, respectively [50]. The distinct Raman band at $773 \mathrm{~cm}^{-1}$ was associated with the presence of the $\mathrm{VO}_{x}$ species on the surface of Ni-V/KIT-6 [51]. The sharp Raman peak observed at $1030 \mathrm{~cm}^{-1}$, which was close to $1036 \mathrm{~cm}^{-1}$ derived from the $\mathrm{V}=0$ stretching vibration of isolated $\mathrm{VO}_{4}$ species according to the previous report [52]. Meanwhile, a weak shoulder peak appeared at $987 \mathrm{~cm}^{-1}$, close to a $995 \mathrm{~cm}^{-1}$ mode, that was originated from polymeric vanadyl species in diverse environments, indicating that some

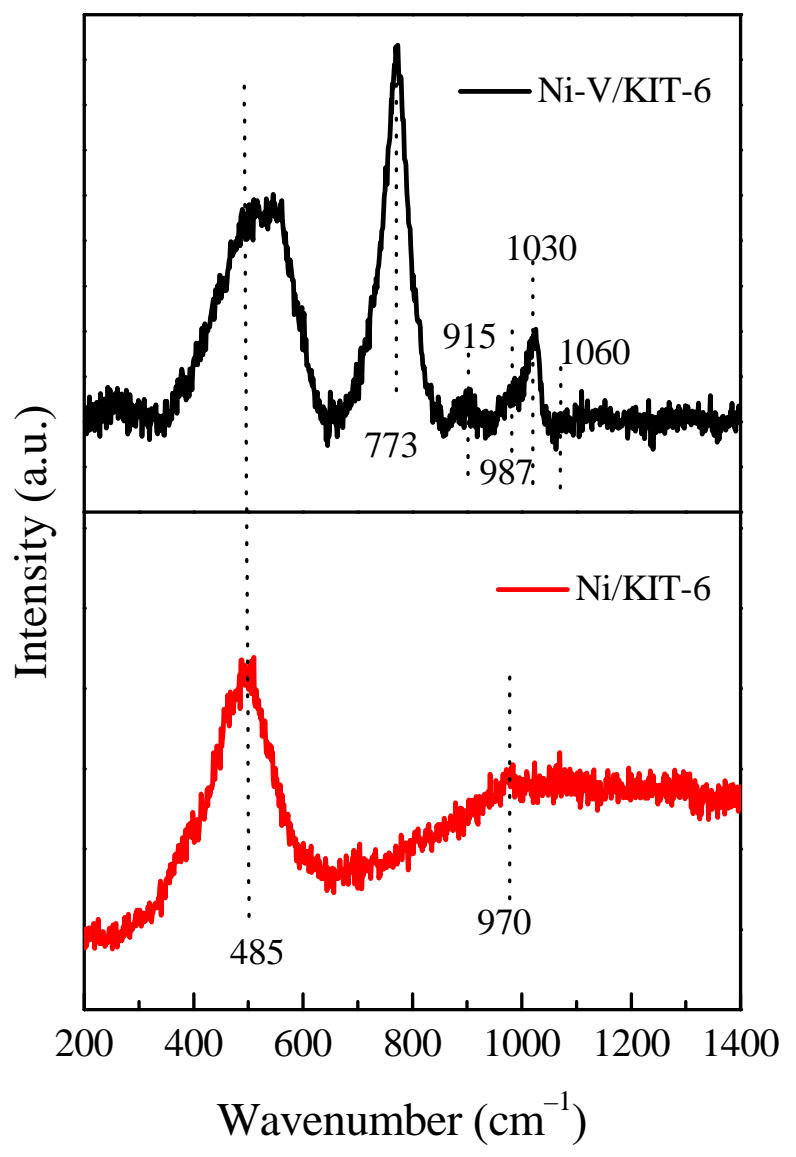

Fig. 9. Raman spectra of Ni/KIT-6 and Ni-V/KIT-6.
V species were highly dispersed on 3D-mesoporous KIT-6. In addition, two new Raman peaks were observed at 915 and $1060 \mathrm{~cm}^{-1}$, which were considered as the formation of the V-O-Si stretching mode [53,54], confirming a strong interaction with 3D-mesoporous KIT-6 as indicated from the previous result of $\mathrm{H}_{2}$-TPR analysis.

Based on the analysis mentioned above, the excellent catalytic performance of Ni-V/KIT- 6 was because fine $\mathrm{Ni}$ nanoparticles were introduced into 3D-mesopores and anchored on the internal surface of 3D-mesoporous KIT-6. Due to loading of $\mathrm{V}$ species, an enhanced confinement effect of 3D-mesopores and the strong interaction with 3D-mesoporous KIT- 6 from the formation of the Si-O-V linkage between 3D-mesoporous KIT-6 and V species effectively resisted sintering and coking of Ni nanoparticles, leading to higher catalytic activity and better catalytic stability.

\subsection{Characterization of spent catalysts}

The spent Ni/KIT- 6 and Ni-V/KIT- 6 were further measured using TEM, XRD and TGA after $60 \mathrm{~h}$-lifetime test, and the results were depicted in Fig. 10. As seen from TEM images of the spent Ni/KIT-6 and Ni-V/KIT-6 in Fig. 10(a) and (b), well-ordered 3D-mesopores of the spent Ni-V/KIT-6 was still regular, and $\mathrm{Ni}$ nanoparticles with an average size of around 3 $\mathrm{nm}$ were anchored into 3D-mesopores, which was considered as a favorable factor of better catalytic stability and anti-sintering property of Ni-V/KIT-6. However, the spent Ni/KIT- 6 exhibited relatively serious agglomeration of $\mathrm{Ni}$ nanoparticles, leading to the formation of larger $\mathrm{Ni}$ nanoparticles (more than $5 \mathrm{~nm}$ by TEM), which was caused by the easy migration of $\mathrm{Ni}$ nanoparticles from a relatively weak interaction between active metal and support. As shown in Fig. 10 (c), the spent Ni-V/KIT- 6 presented a similar XRD diffraction peak of Ni nanoparticles compared with those of Ni-V/KIT- 6 , and the average Ni nanoparticle size of the spent Ni-V/KIT- 6 was almost equal to that of the corresponding Ni-V/KIT-6. In contrast, the spent Ni/KIT- 6 displayed a fairly sharp diffraction peaks than Ni/KIT-6, with the average Ni nanoparticle size of $5.8 \mathrm{~nm}$ estimated by XRD. There was no signal corresponding to deposited carbon in XRD and TEM, indicating that deposited carbon probably was amorphous or with very low concentration. Furthermore, the amounts of carbon deposited on the 

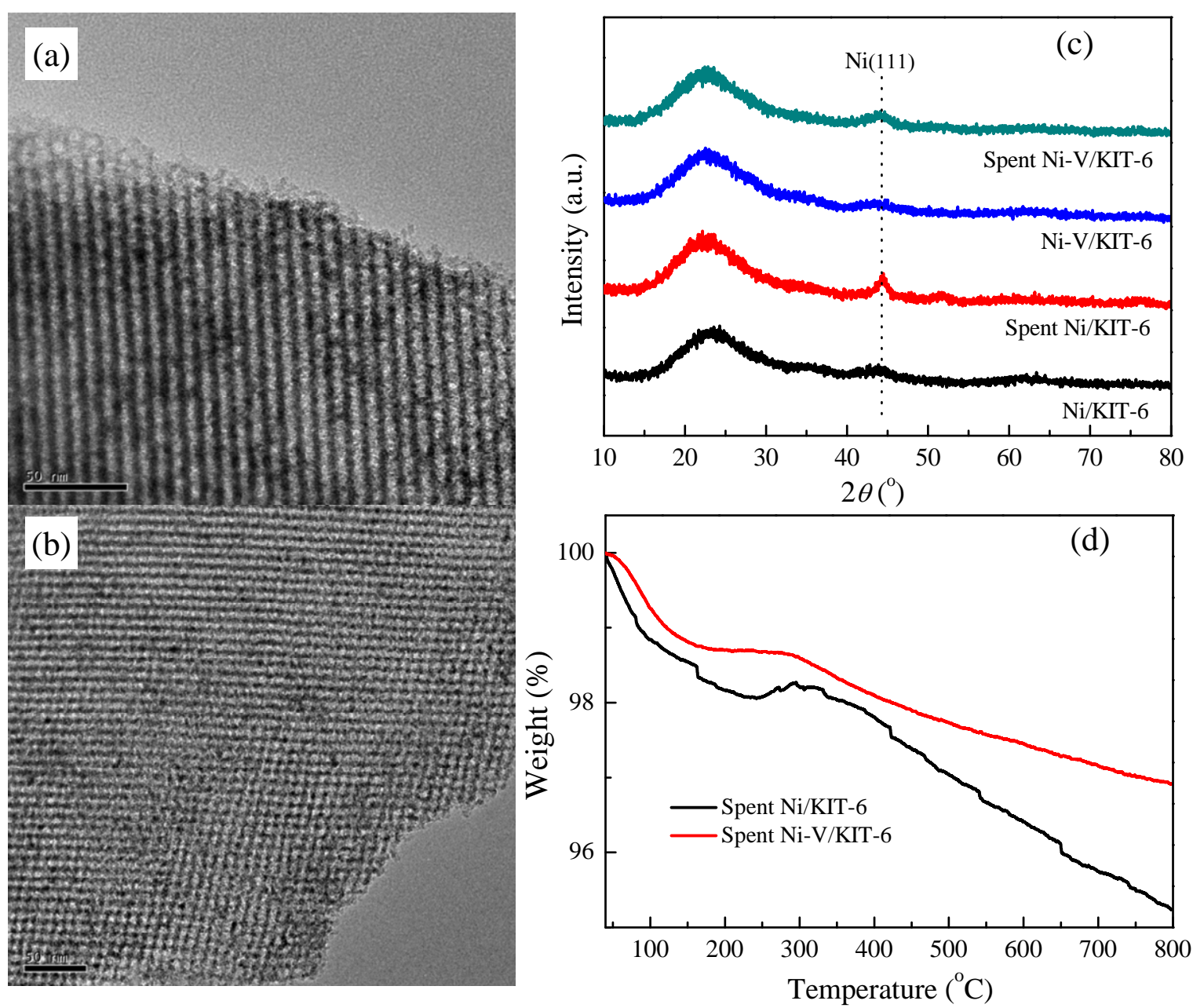

Fig. 10. TEM images of the spent Ni/KIT-6 (a) and Ni-V/KIT-6 (b); (c) XRD patterns of the reduced and spent catalysts; (d) TGA profiles of the spent Ni/KIT- 6 and Ni-V/KIT-6.

spent Ni/KIT- 6 and Ni-V/KIT- 6 were analyzed by TGA, and the results were illustrated in Fig. 10(d). The weight loss percentage from the spent Ni/KIT- 6 was larger than that of the spent Ni-V/KIT-6, reflecting better anti-coking property of $\mathrm{Ni}-\mathrm{V} / \mathrm{KIT}-6$.

\section{Conclusions}

Ni-based catalysts modified by various promoters were successfully synthesized using 3D-mesoporous KIT-6 as a support modified by ethylene glycol with an incipient-wetness impregnation method. Compared to Ni/KIT-6, promoter-modified catalysts exhibited better low-temperature catalytic activity for $\mathrm{CO}$ methanation at $1 \mathrm{~atm}, 250-400{ }^{\circ} \mathrm{C}$ and a relatively high WHSV of $60000 \mathrm{~mL} /(\mathrm{g} \cdot \mathrm{h})$, and Ni-V/KIT-6 possessed the best catalytic performance with its maximal $\mathrm{CO}$ conversion of $100 \%$ and $\mathrm{CH}_{4}$ yield of $85 \%$ at a relatively low reaction temperature of $350{ }^{\circ} \mathrm{C}$. In a 60 h-lifetime test conducted at $500{ }^{\circ} \mathrm{C}, 1 \mathrm{~atm}$ and WHSV of $60000 \mathrm{~mL} /(\mathrm{g} \cdot \mathrm{h})$, Ni-V/KIT-6 displayed an excellent resistance to Ni nanoparticles sintering and coke formation. The catalysts were measured by $\mathrm{N}_{2}$ adsorption-desorption, XRD, $\mathrm{H}_{2}$-TPR, $\mathrm{H}_{2}$-TPD, FT-IR, Raman, TEM, EDX and TGA, and the results revealed that the enhanced catalytic performance of Ni-V/KIT- 6 was due to the highest dispersion of Ni nanoparticles (26.5\%) accompanied by improved reducibility to produce the most $\mathrm{Ni}$ active sites, the intimate interaction with support from the formation of $\mathrm{Si}-\mathrm{O}-\mathrm{V}$ linkage and an enhanced confinement effect of 3D-mesopores leading to the formation of small Ni nanoparticles. Similarly, Ni-Ce/KIT-6, Ni-La/KIT-6, and Ni-Mn/KIT-6 possessed larger $\mathrm{H}_{2}$ uptakes and higher dispersion of $\mathrm{Ni}$ nanoparticles than those of Ni/KIT-6. Additionally, the formation of the Si-O-V linkage and and enhanced confinement effect of 3D-mesopores by the addition of $\mathrm{V}$ species were favorable to generate small size of Ni nanoparticles and further prevent the aggregation of $\mathrm{Ni}$ nanoparticles during high-temperature reduction and CO methanation. As a result, our current work suggested that Ni-V/KIT-6 with excellent catalytic performance and stability should be considered as a promising candidate for $\mathrm{CO}$ methanation.

\section{Acknowledgments}

The authors gratefully acknowledge financial supported by the Fundamental Research Funds for the Central Universities (No.2015XKMS061), and sincerely appreciate Prof. Xinbin Ma 


\section{Graphical Abstract}

Chin. J. Catal., 2017, 38: 1127-1137 doi: 10.1016/S1872-2067(17)62862-6

Highly dispersed Ni nanoparticles on 3D-mesoporous KIT-6 for CO methanation: Effect of promoter species on catalytic performance

Hong-Xia Cao, Jun Zhang, Cheng-Long Guo, Jingguang G.Chen *, Xiang-Kun Ren *

China University of Mining and Technology, China; Columbia University, USA

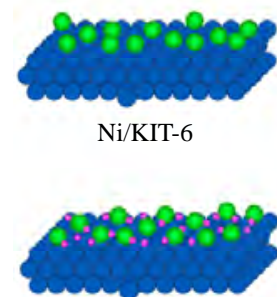

Ni-M/KIT-6

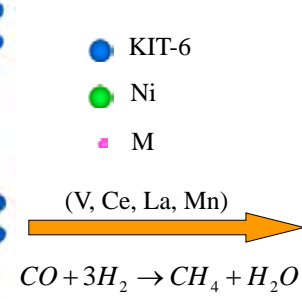

$\mathrm{CO}+3 \mathrm{H}_{2} \rightarrow \mathrm{CH}_{4}+\mathrm{H}_{2} \mathrm{O}$
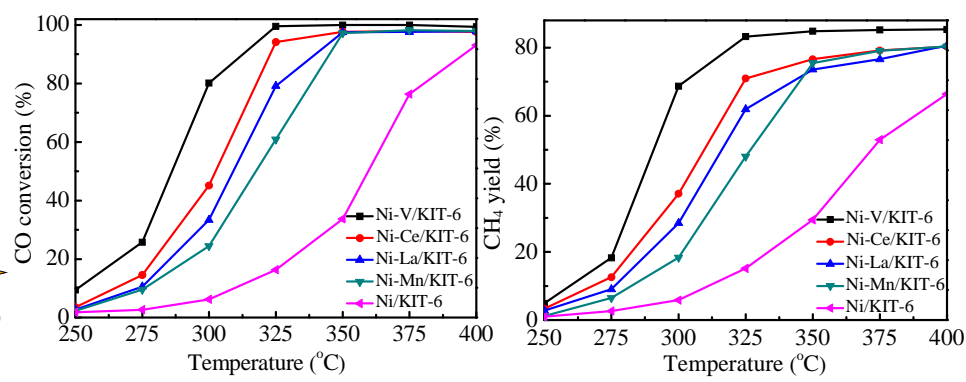

The addition of promoter species can improve the catalytic performance at the low-temperature, and the Ni-V/KIT-6 exhibited the best catalytic performance for CO methanation due to higher dispersion of Ni nanoparticles on 3D-mesoporous KIT-6.

from Tianjin University for his suggestion on the experiment.

\section{References}

[1] M. Götz, J. Lefebvre, F. Mörs, A. M. D. Koch, F. Graf, S. Bajohr, R. Reimert, T. Kolb, Renew. Energy, 2016, 85, 1371-1390.

[2] L. Pandian, S. K. Min, D. P. Eun, Appl. Catal., 2016, 513, 98-105.

[3] X. J. Hu, W. J. Yan, W. H. Ding, J. Yu, Y. Huang, Chin. J. Catal., 2013, $34,1720-1729$

[4] L. Bian, W. H. Wang, R. Xia, Z. H. Li, RSC Adv., 2016, 6, 677-686.

[5] J. Sehested, S. Dahl, J. Jacobsen, J. R. Rostrup-Nielsen, J. Phys. Chem. $B, \mathbf{2 0 0 5}, 109,2432-2438$.

[6] L. K. Zhou, Z. L. Li, J. F. Pang, M. Y. Zheng, A. Q. Wang, T. Zhang, Chin. J. Catal., 2015, 36, 1694-1700.

[7] S. Carenco, C. Sassoye, M. Faustini, P. Eloy, D. P. Debecker, H. Bluhm, M. Salmeron, J. Phys. Chem. C, 2016, 120, 15354-15361.

[8] W. B. Shi, X. L. Liu, J. L. Zeng, J. Wang, Y. D. Wei, T. Y. Zhu, Chin. J. Catal., 2016, 37, 1181-1192.

[9] W. Kim, K. Y. Koo, H. J. Lee, Y. G. Shul, W. L. Yoon, Int. J. Hydrogen Energy, 2015, 40, 10033-10040.

[10] H. Liu, Y. Lin, Z. Ma, Chin. J. Catal., 2016, 37, 73-82.

[11] C. Galletti, S. Specchia, V. Specchia, Chem. Eng. J., 2011, 167, 616-621.

[12] M. A. Lucchini, A. Testino, A. Kambolis, C. Proff, C. Ludwig, Appl. Catal. B, 2016, 182, 94-101.

[13] S. Abate, K. Barbera, E. Giglio, F. Deorsola, S. Bensaid, S. Perathoner, R. Pirone, G. Centi, Ind. Eng. Chem. Res., 2016, 55, 8299-8308.

[14] H. Zhang, Y. Y. Dong, W. P. Fang, Y. X. Lian, Chin. J. Catal., 2013, 34, 330-335.

[15] T. Miyao, S. Sakurabayashi, W. H. Shen, K. Higashiyama, M. Watanabe. Catal. Commun., 2015, 58, 93-96.

[16] X. Li, X. Z. Yang, H. D. Tang, H. Z. Liu, Chin. J. Catal., 2011, 32, 1400-1404.

[17] J. J. Gao, C. M. Jia, J. Li, M. J. Zhang, F. N. Gu, G. W. Xu, Z. Y. Zhong, F. B. Su, J. Energy Chem., 2013, 22, 919-927.

[18] A. M. Zhao, W. Y. Ying, H. T. Zhang, H. F. Ma, D. Y. Fang, Catal. Commun., 2012, 17, 34-38.

[19] M. Tao, X. Meng, Y. H. Lv, Z. C. Bian, Z. Xin, Fuel, 2016, 165,
289-297.

[20] M. Tao, Z. Xin, X. Meng, Z. C. Bian, Y. H. Lv, Fuel, 2017, 188, 267-276.

[21] B. W. Lu, Y. W. Ju, T. Abe, K. Kawamoto, RSC Adv., 2015, 5, 56444-56454.

[22] J. Y. Zhang, Z. Xin, X. Meng, M. Tao, Fuel, 2013, 109, 693-701.

[23] B. Dai, B. Wen, M. Y. Zhu, L. H. Kang, F. Yu, RSC Adv., 2016, 6, 66957-66962.

[24] M. A. A. Aziz, A. A. Jalil, S. Triwahyono, R. R. Mukti, Y. H. Taufiq-Yap, M. R. Sazegar, Appl. Catal. B, 2014, 147, 359-368.

[25] Q. Liu, F. N. Gu, X. P. Lu, Y. J. Liu, H. F. Li, Z. Y. Zhong, G. W. Xu, F. B. Su, Appl. Catal. A, 2014, 488, 37-47.

[26] Y. Zeng, H. F. Ma, H. T. Zhang, W. Y. Ying, D. Y. Fang, Fuel, 2015, $162,16-22$.

[27] G. J. Zhi, X. N. Guo, Y. Y. Wang, G. Q. Jin, X. Y. Guo, Catal. Commun., 2011, 16, 56-59.

[28] K. H. Song, X. Yan, D. J. Koh, T. Kim, J. S. Chung. Appl. Catal. A, 2017, 530, 184-192.

[29] D. E. Rivero-Mendoza, J. N. G. Stanley, J. Scott, K. F. Aguey-Zinsou. Catalysts, 2016, 6, 170-185.

[30] K. C. Zhao, Z. H. Li, L. Bian. Front. Chem. Sci. Eng., 2016, 10, 273-280.

[31] J. Happel, I. Suzuki, P. Kokayeff, V. Fthenakis, J. Catal., 1980, 65, 59-77.

[32] J. Liu, C. M. Li, F. Wang, S. He, H. Chen, Y. F. Zhao, M. Wei, D. G. Evansa, X. Duan, Catal. Sci. Technol., 2013, 3, 2627-2633.

[33] P. Xu, Z. X. Wu, J. G. Deng, Y. X. Liu, S. H. Xie, G. S. Guo, H. X. Dai, Chin. J. Catal., 2017, 38, 92-105.

[34] B. T. Li, X. Luo, J. Huang, X. J. Wang, Z. X. Liang, Chin. J. Catal., 2017, $38,518-528$.

[35] F. Kleitz, S. H. Choi, R. Ryoo, Chem. Commun., 2003, 2136-2137.

[36] Q. Liu, J. J. Gao, M. J. Zhang, H. F. Li, F. N. Gu, G. W. Xu, Z. Y. Zhong, F. B. Su, RSC Adv., 2014, 4, 16094-16103.

[37] X. Z. Yang, Wendurima, G. J. Gao, Q. Q. Shi, X. Wang, J. N. Zhang, C. H. Han, J. Wang, H. L. Lu, J. Liu, M. Tong, Int. J. Hydrogen Energy, 2014, $39,3231-3242$.

[38] F. Kleitz, F. Berube, R. Guillet-Nicolas, C. M. Yang, M. Thommes, J. Phys. Chem. C, 2010, 114, 9344-9355.

[39] J. Sun, Q. B. Kan, Z. F. Li, G. L. Yu, H. Liu, X. Y. Yang, Q. S. Huo, J. Q. 
Guan, RSC Adv., 2014, 4, 2310-2317.

[40] H. D. Li, J. Ren, X. Qin, Z. F. Qin, J. Y. Lin, Z. Li, RSC Adv., 2015, 5, 96504-96517.

[41] X. Y. Liu, B. Z. Tian, C. Z. Yu, F. Gao, S. H. Xie, B. Tu, R. C. Che, L. M. Peng, D. Y. Zhao, Angew. Chem. Int. Ed., 2002, 41, 3876-3878.

[42] Q. Zhang, T. J. Wang, B. Li, T. Jiang, L. L. Ma, X. H. Zhang, Q. Y. Liu, Appl. Energy, 2012, 97, 509-513.

[43] C. F. Wu, L. Z. Wang, P. T. Williams, J. Shi, J. Huang, Appl. Catal. B, 2011, 108, 6-13.

[44] S. Velu, S. K. Gangwal, Solid State Ionics, 2006, 177, 803-811.

[45] Z. C. Liu, J. Zhou, K. Cao, W. M. Yang, H. X. Gao, Y. D. Wang, H. X. Li, Appl. Catal. B, 2012, 125, 324-330.

[46] M. Piumetti, B. Bonelli, P. Massiani, S. Dzwigaj, I. Rossetti, S. Casale, M. Armandi, C. Thomas, E. Garrone, Catal. Today, 2012, 179, 140-148.

[47] Y. Y. Fu, Y. N. Wu, W. J. Cai, B. Yue, H. Y. He, Sci. China Chem., 2015,
$58,148-155$

[48] W. C. Zhang, Y. L. Guo, Y. Q. Wang, Y. Guo, G. Z. Lu, J. Rare Earths, 2010, 28, 369-375.

[49] V. K. Tomer, S. Duhan, P. V. Adhyapak, I. S. Mulla, J. Am. Ceram. Soc., 2015, 98, 741-747.

[50] G. Ricchiardi, A. Damin, S. Bordiga, C. Lamberti, G. Spano, F. Rivetti, A. Zecchina, J. Am. Chem. Soc., 2001, 123, 11409-11419.

[51] X. T. Gao, S. R. Bare, B. M. Weckhuysen, I. E. Wachs, J. Phys. Chem. B, 1998, 102, 10842-10852.

[52] Q. L. Liu, J. M. Li, Z. Zhao, M. L. Gao, L. Kong, J. Liu, Y. C. Wei. Catal. Sci. Technol., 2016, 6, 5927-5941

[53] G. Xiong, C. Li, H. Y. Li, Q. Xin, Z. C. Feng, Chem. Commun., 2000, 8, 677-678.

[54] G. Du, S. Lim, M. Pinault, C. Wang, F. Fang, L. Pfefferle, G. L. Haller, J. Catal., 2008, 253, 74-90.

\title{
三维介孔KIT-6上高分散Ni纳米粒子用于CO甲烷化: 助剂对催化性能的影响
}

\author{
曹红霞 ${ }^{\mathrm{a}, \mathrm{b}}$, 张 军 ${ }^{\mathrm{a}}$, 郭成龙 ${ }^{\mathrm{c}}$, 陈经广 ${ }^{\mathrm{d},{ }^{*}}$, 任相坤 ${ }^{\mathrm{a}, \text {, }}$ \\ a 中国矿业大学低碳能源研究院, 江苏徐州221008, 中国

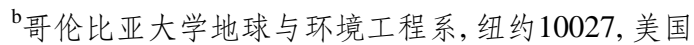 \\ ' 中国矿业大学电气与动力工程学院, 江苏徐州221116, 中国

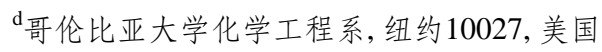

摘要: 作为煤制天然气的核心技术之一, $\mathrm{CO}$ 甲烷化工艺的开发基础便是高效催化剂的研制. 目前, CO甲烷化催化剂主要 采用 $\mathrm{Ni}$ 作为活性组分, 但如何保持其具有较高的催化活性和优异的高温稳定性, 仍为当今不得不面临的棘手问题. 本文以 乙二醇改性的三维介孔KIT-6为载体, 利用其较高的比表面积、可调孔径、独特的双螺旋三维孔道结构等特点, 通过湿式浸 渍法成功制备了由助剂改性的 $\mathrm{Ni}$ 基催化剂, 探讨了 $\mathrm{V}, \mathrm{Ce}, \mathrm{La}, \mathrm{Mn}$ 等不同助剂对 $\mathrm{Ni}$ 基催化剂CO甲烷化催化性能的影响. 分 别采用X射线衍射、氢气程序升温还原、氢气程序升温脱附、傅里叶变换红外光谱、透射电子显微镜、能量色散X射线光 谱、激光拉曼光谱和热重分析等手段对催化剂特性进行了表征. 结果显示, Ni-V/KIT-6具有最高的Ni纳米粒子分散性 (26.5\%)和催化还原性, 产生了最多的活性位, 同时, Si-O-V的形成增强了金属-载体间相互作用, 并因载体的三维介孔限制 效应而形成较小 $\mathrm{Ni}$ 纳米粒子, 这些均有助于提升 $\mathrm{Ni}$ 基催化剂CO甲烷化的催化性能和稳定性. 在常压、250-400 ${ }^{\circ} \mathrm{C}$ 和60000 $\mathrm{mL} /(\mathrm{g} \cdot \mathrm{h})$ 空速的实验条件下对催化剂进行了催化活性评价测试. 结果表明, 助剂提高了CO甲烷化低温催化活性, 其中, Ni-V/KIT-6在 $350{ }^{\circ} \mathrm{C}$ 的条件下实现了CO的完全转化, $\mathrm{CH}_{4}$ 产率也高达 $85 \%$; 其在常压、 $500{ }^{\circ} \mathrm{C}$ 和 $60000 \mathrm{~mL} /(\mathrm{g} \cdot \mathrm{h}$ )空速的操作条 件下所进行的稳定性测试结果还显示, Ni-V/KIT-6也具有优异的抗烧结和抗积碳能力, 展示了良好的高温稳定性. 因此, Ni-V/KIT-6是一种具有广阔应用前景的CO甲烷化催化剂.

关键词: 镍基催化剂; 甲烷化; 助剂; 载体; 三维介孔

收稿日期: 2017-04-09. 接受日期: 2017-05-23. 出版日期: 2017-07-05.

*通讯联系人. 电话/传真: +1-212-854-6166; 电子信箱: jgchen@columbia.edu

\#通讯联系人. 电话/传真: (0516)83883501; 电子信箱: xiangkunren@cumt.edu.cn 基金来源：中央高校基本科研业务费专项资金资助(2015XKMS061).

本文的英文电子版由Elsevier出版社在ScienceDirect上出版(http://www.sciencedirect.com/science/journal/18722067). 